\title{
No Laughing Matter?A Short History of German Comedy
}

\author{
Chris Ritchie, James Harris
}

\begin{abstract}
This article is the first stage of research for the book "No Laughing Matter: A Short History of German Comedy' by Chris Ritchie and James Harris which will look at some key moments in German comedy, representations of Germans in English language comedy and 'and also take a look at the current Berlin comedy scene. It begins with an example of how the British, or particularly the English, represent the 'comedy German', and is followed by an overview of some key moments in the history of German comedy, in particular the work of Hans Sachs and the development of $20^{\text {th }}$ century cabaret. The second section then looks at how the Germans view English comedy through an analysis of the sketch Dinner for One and Monty Python's German-language episode.
\end{abstract}

\section{Preface}

"Don't mention the war." (The Germans, Fawlty Towers, Series 1 \#6)

The Germans have no sense of humour. This is the orthodoxy of the English mindset; expressed bluntly as that or as a recent German perspective more eloquently had it, "(to the British) the Krauts are a humorless people, who vacillate between grumbling seriousness and sentimental romanticism and are unable to distance themselves from the seriousness of life" ${ }^{1}$. Despite these suggestions, humour remains an essential part of human culture, a by-product of both language and social interaction and in Western Europe it is highly dubious to assert that any culture lacks comic objects, linguistic humour or comedy taboo. What the English mean when they say the Germans lack a sense of humour is that 'they do not possess the same sense of humour as us.' In any Berlin Kneipe or a London pub, humour is a significant element. How loudly

1 'Monty Python bei Brits und Krauts', by Hans-Dieter Geifert in Schnitt magazine (www . schnitt.de). The original text runs so: "In (Britischen) -Augen sind die 'Krauts' ein humorloses Volk, das zwischen sauertöpfischem Ernst und sentimentaler Romantik hin- und herschwankt und unfähig ist, sich vom Ernst des Lebens zu distanzieren“; the translation given above is from James Harris. 
and indeed just how it is expressed is a different matter. European cultures differ within themselves concerning humour in matters of time and place, of humour's role within entertainment culture and how either separate or integral to everyday discourse it is.

Being Germanophiles as well as writers and performers interested in many aspects of comedy, we decided to look at key moments in German comedy to see how traditionally humour is expressed. We decided to conduct research into representations of Germans in English language comedy using stage and television examples as a model. This article is the first part of ongoing research into the developments in over 500 years of German comedy. It is undertaken not without trepidation; perhaps it is part of our own incipient arrogance to offer criticism of another culture's comic heritage but in reality it stems from an interest in German culture and history. We apologise in advance for any clumsy toe-treading or rash generalisations of either English or German culture.

The German has been portrayed as usually authoritarian and humourless in British comedy such as 'Allo 'Allo, Dad's Army, and Morecambe and Wise sketches. A particular episode of Fawlty Towers, The Germans, appears to offer an insight into the aforementioned negative condition of the Anglo-German relationship. The little Englander's vitriol is given full reign following an incident with a moose head and a subsequent concussion. A German party is set to arrive at the hotel which will inevitably lead to disaster: contact with anything remotely foreign does not bring out the best in certain English people. The Fawlty Tower Germans are stiff, formal and speak Basil's language even though he cannot speak theirs. He does not realise who they are at first: "Oh German? I thought there was something wrong with you." He desperately tries to avoid mentioning the war but the more he represses it, the worse the situation becomes. Fawlty fails to impress his guests with his comedy accent, jokes, impressions and spooky leg walk, finally showing his real feelings by shouting: "You have absolutely no sense of humour, do you?" (the usual retort to someone who has not found unfunny jokes funny). The 'humourless' cliché is in place. There is no denying the sustained popularity of Fawlty Towers and the accurate reflection of an English attitude but the question of whether we are laughing at Basil or with him remains an ambiguous one.

The subtitle of this project, A Short History of German Comedy, is bound to elicit jokes such as 'it will be a short one as well!' among others. Nonetheless, it is a worthwhile endeavour; not only to dispel the myth but also to find similarities in comic development in the two countries as well as in a wider European context. Many Italian commedia dell arte troupes travelled through Europe from the $16^{\text {th }}$ century onwards reaching Germany and England around the same time and spreading their influence throughout the theatre. The German clown Hanswurst is not too far from being a traditional commedia figure, though this is not to over-credit commedia with being the original clowns.

In Munich there is a museum dedicated to the comedian Karl Valentin. Where in England is the equivalent? We may have our Max Miller, Tony Hancock 
and Eric Morecambe statues ${ }^{2}$ but no museum for comedy, and at universities we have just a few units in comedy and only one degree dedicated entirely to comedy at Southampton Solent University. The English pride themselves on their sense of humour, and rightly so; Shakespeare, Jonson and Johnson, Milligan and Monty Python or Gervais and Morris are all noteworthy amongst note-worthies yet a national archive or resource is still lacking. However, it is important to look at some developments in German comedy, some of which parallel developments in English comedy.

\section{Key Moments in German Comedy}

"Nothing in fact is ever said which has not been said before." (Terence)

"Everything has been thought of before, but the problem is to think of it again." (Goethe)

It may come as a surprise to some in the English speaking comedy world, but the revival of comedy in Germany began during the Renaissance with the translation and modifications of Roman comedies during the $10^{\text {th }}$ century by, of all people, a German nun. In 1493 adaptations of Terence were discovered, written by Hrostwitha of Gandersheim, several of which survive. The plot of Dulcitius is based around the eponymous Governor's attempts to molest a clutch of virgins whom he has imprisoned in the pantry. Bizarrely, he goes into the darkened room fondling assorted utensils mistaking them for the three beauties (an understandable error). The virgins' honour is preserved but two are consigned to the flames and the third to a brothel. Their souls are saved and their tormentors condemned to hell. The morality of the play chimed agreeably with humanist scholars of the $15^{\text {th }}$ century as it conformed to the didactic nature of much subsequent German comedy: the motifs of sinners and saved, corruption and punishment, the duality of body and soul are recurrent. Terence was used in an exemplary manner for moralising criticism: the plays were rewritten, adapted and modified for use in Reformation education as the lessons, relative cleanliness, language and complex structure (the double plot) retained their appeal.

\subsection{Hans Sachs}

"[...] excessive in food and drink, / Lusting for delicates; made you stink." (Gillespie 1992: 21). ${ }^{3}$

The work of Hans Sachs is considered important, especially because there are extant texts, albeit ones of varying quality. Sachs' verse and plays often dealt

\footnotetext{
${ }^{2}$ In Brighton, Birmingham and Morecambe respectively - although the statue of Max has been temporarily removed.

3 This play is rendered in a neat modern translation by Martin W. Walsh that captures the energy, clever verbiage and ribald humour of the later mountebank/mock-doc character type.
} 
with moral transgression: sin is punished. Fool Surgery (1557) features the spoof doctor that would become typical throughout much subsequent comedy, in the spiel of Il Dottore from commedia dell 'arte and later English mummers plays, as well as the mountebank figure most notably seen in Ben Jonson's Volpone (1605). As in the English Interludes, comic figures are used to get the crowd in before the sermonising begins. People do not like their morality straight. The comedy of the play - its language, physical humour, absurdity and bawdy toilet-jokes in the text - tempers the lesson.

The doctor enters addressing his tongue twisting list of ailments and promissory cures to the audience directly, thereby cheekily implicating them in the later prognosis. A sick man approaches on crutches, his stomach distended. The doctor asks him to eat a large Blutwurst which is then washed down with his own urine. Waving a knife around the doctor diagnoses that "This man is stuffed chock full of Fools!" (Gillespie 1992: 17) and, with a slice of the knife, he begins to extract seven fools, running down the sins one by one. The last to go is, appropriately enough, sloth. The patient is cured, his selfishness purged and he vows to help the doctor cut out the sins from the town or audience.

\subsection{Nachspiel}

Nachspiel is a loose term referring to short comic playlets, parodies or after-pieces to tragedies mainly from the $18^{\text {th }}$ century. The surviving Nachspiel texts are less plays in the classical Terentian sense with dialogue, exposition, complication and so on, and more like tableaux where each successive character appears to perform their set piece. The main dialogues occur between the principle characters but these would often have been punctuated by commedia style lazzi and improvisation performed by either the particular German clown, Hanswurst or Harlekin (Harlequin) and his female co-conspirator, Colombine, both clearly figures from the commedia. Hanswurst was a rustic, base-driven clown, ever seeking food, beer or sexual gratification; a braggart and vulgarian, whose background is indicated by costume of a large black hat, baggy trousers and, at times, a wooden dagger which connects him to the Tudor vice who often carried a similar sword. This operates as a symbol of impotence - pointless and without threat. In these clowns, we see the beginnings of the solo comedian directly addressing his natural constituency in the audience.

The use of clowns and coarser humour held appeal to many and had its antecedents in 'market comedy' dating back through the medieval period to Roman times. As with Shakespeare these clowns became a principal attraction and gained reputations for their work. Franz Schuch played Hanswurst, thriving on the interaction and improvisation demanded by the role, leading a successful itinerant troupe from 1740 to 1764 with Hanswurst as his "tool for social criticism and commentary" (John 1991: 31).

Clowns are always able to breach the fourth wall through their banter, heckling and fundamental disregard for illusion. Johann Martin Leper became a prominent Harlekin in Leipzig. John makes light of the 1920s academic Prick 
and his research into Koch, a dramaturg who hired Lepper. The comedian had "an extensive personal collection of women's shoes, stockings and slippers with the names of the former owners attached." (ibid.: 67) It is good to see that comedians have always been well-balanced, focused individuals.

German comedy of this time was subject to numerous influences including that of the commedia dell arte with its continuously travelling ensembles; the English itinerant players who had covered much of Europe; the influence of French comedy that had spread across the border; and a European minstrels circuit, going South in winter, North in summer, that had developed around the Messen, markets and carnivals where trade could be plied.

The theatre became more static and bourgeois in the $18^{\text {th }}$ century. The vagaries and whims of authority determined what could be on the comedy stage. In $18^{\text {th }}$ century Berlin, the theatre

was intimately related to the tastes and preferences of the Prussian king who held full authority over permission to perform, and who provided strong financial subsidies to companies he wished to encourage, to the detriment of others. (ibid.: 29).

The Nationaltheater developed in the $18^{\text {th }}$ century, generally under the control of the court, the increase in established theatre houses in Europe, and the concern about itinerant players who performed at markets, fayres and taverns dealing with matters possibly outside of the control of the state and its censors, led to a shift in the style of comedy.

\subsection{Nineteenth Century Comedy}

There is a temptation to surmise that the perceived lack of German humour comes from the relative paucity of writers contributing to the overall history or canon of comedy. Indubitably, Schiller and Schlegel, despite their achievements, do not share the same international recognition for their comedy as Shakespeare, Moliere or Wilde. In the $19^{\text {th }}$ century, whilst the music hall appeared in England, America had vaudeville and France saw the expansion of cabaret, Germany had as yet no equivalent for the comedy performances employing direct address common to these other countries. This did not mean that there was no comedy. The industrial revolution in Germany meant the increase in leisure time and the opening of new theatres. A unique form of 'Berlin Comedy' developed, initially influenced by Nestroy's Viennese comedies. Franz Wallner created "familiar Berlin character types like plumbers, carpenters, coachmen, and chambermaids, all speaking the distinctive dialect of Berlin and its surroundings." (Grange 1996: 1f). In the latter half of the century, Theodor Lebrun took over Wallner's theatre and, realising the waning fortunes of the Berlin product, put on plays aimed at the bourgeois theatre crowd, especially plays by Adolf L'Arronges who exploited "Discoveries, reversals, and mistaken identities" (ibid.: 3). 


\subsection{Cabaret}

“Joking was one of cabaret's major attributes.” (Jelavich 1993: 30)

German cabaret is forever associated with Marlene Dietrich in the Blue Angel and Fraulein Sally Bowles in the musical Cabaret, or for those with a more learned bent, the songs of Brecht \& Weill's Threepenny Opera (and Tom Waits' numerous borrowings), perhaps performed by Ute Lemper. Enjoyable though they are, these are not the real thing: what they can and do suggest is flavour and context. Our impressions of Weimar Cabaret are of cigar smoke, glasses of beer, maybe champagne, strong sexual flavours, perhaps transvestism, all soundtracked by a nasal, cynical voice over banjo and bugle. 'Cabaret' could be anything from seedy to mainstream, small dive to traditional theatre, incorporating performers of diverse abilities and material of variable originality.

German cabaret was influenced by the French Chat Noir which opened in 1881 or bawdier concepts such as the Moulin Rouge with its mix of music, comedy, satire and skin - a potent mix and one which quickly expanded throughout Berlin. Proprietors of smaller 'non-theatre' venues could sidestep the licensing issues and provide cabaret entertainment, often of dubious quality, for drinkers and diners. The stages were of various sizes, acoustics often unpredictable and the audiences inattentive and raucous. The relative informality of the cabaret could be frustrating to a performer seeking to address a secure audience rather than one that is constantly getting up and down and not necessarily paying undivided attention. Proceedings would be guided by the conferencier or Master of Ceremonies but there could always be heckling and improvisation. The conferencier mediates between performer and audience using direct address.

European comedy has always been, although less recently, scrutinised by the censors: provocative, disrespectful, satirical, shocking, all these things concern not only the comedian but also the constables. Under Kaiser Wilhelm, cabaret was subject to censorship but the authorities clearly understood the cathartic nature of comedy. Cabaret enabled the expression of disquiet on stage, which for the state was preferable to it being expressed on the streets. Cabaret becomes a laughing house where proscribed ideas can be vented with relatively little 'real' effect. During the time of the Weimar republic censorship was more relaxed and satire was tempered by audience expectation.

Cabaret had distinctly modernist elements, reflecting and catering to the expanding cosmopolis: the increase in leisure time; industrialisation and mass production; jazz, new musical styles and the development of instruments such as the saxophone, the cheaper banjo and its larger relative, the guitar; democratic politics, feminism, socialism and anarchism and their ugly cousin, nationalism; and the rise of the popular song. It dealt with what much of pop culture has always dealt with: boys and girls, dressing up, sex and sexual innuendo, celebrity and politics to varying degrees. The immediacy of the material, like with so much satire or topical material, renders it irretrievably dated. For cabaret a fourth wall is broached and intimacy becomes important: the performers address the audience directly in a performance both immediate 
and 'spontaneous': cabaret happens now, when the fourth wall is broached and the audience are involved not as mute spectators but as participants. As the cabaret venues varied in size, the degrees of such 'intimacy' were consequently effected. Cabaret was criticised for its vulgarity, lewdness, decadence and low value in relation to 'proper theatre' (in the same way that comedy has always been denigrated as the scruffy cousin of tragedy). Cabaret did not escape the perennial dispute about entertainment versus high culture. This is not to say cabaret cannot achieve serious commentary: it is surely always possible to express complex ideas within a populist format.

The first Berlin cabaret was opened in 1901 by Ernst von Wolzogen who offered "presentations of a dramatic nature, such as pantomimes, marionette plays, dialogues, and so forth" (Jelavich 1993: 38). Despite his initial lofty intentions and critical approval, the entertainment vote held sway and the audience demanded more risqué material. Max Reinhardt's Sound and Smoke cabaret began shortly after as a weekly semi-private affair with actors improvising parodies of established theatre pieces as well as the dreadful sounding "Diarrhoestia." An invited audience saw a mixture of self-referential material and parody that did not translate to the general public. Sound and Smoke adjusted their material to a more accessible slant due to its debts.

As the political context changed, cabaret likewise focussed on certain issues. With the First World War looming, cabarets often closed due to lack of performers and audience members; others became dominated by nationalist sentiment and a more conformist operetta style became the popular draw. The focus on sexuality shifted from a bawdy and licentious tone to one emphasising marital fidelity.

Following the war the content of cabaret changed and venues proliferated again. Not all cabarets took place in cafes or bars; for example, The Cabaret of Comedians (Kaberett der Komiker - Kadeko) was founded in 1924 by Kurt Robitschek and comedian Paul Morgan and was housed in its own premises (designed by Erich Mendelssohn ${ }^{4}$ ) which could prove difficult to fill.

"You know, when I look at you from up here, it makes me want to puke. You laugh and laugh. You even laugh at your own stupidity." Red Revel Revue actor loses it on stage. (ibid.: 224).

During the Weimar Republic, cabaret became more polarised: some audiences liked the satirical bite while others preferred a less didactic night out. The left seized upon the possibilities of using cabaret as propaganda - whether this was funny or used much comedy is debatable as the songs and skits seem entertaining rather than comic (and certainly the earnest and comedic coexist uneasily). Agit-troupes such as Meyerhold's Red Revel Revue, Red Megaphone or Red Hammer indicate the political tone of proceedings. There was a concern that the audience should not see "the entertainment as a safety valve for discontent but rather as a spur to action." (ibid.: 224). The police became

\footnotetext{
${ }^{4}$ Mendelssohn also designed the remarkable pavilion at Bexhill-On-Sea, Sussex, along with Serge Chermayeff.
} 
concerned over political tensions, censoring what was clearly an accessible and popular form of propaganda. Later, it continued to worry Goebbels who in reference to the Cabaret of Comedians in 1939 was promising that "Political jokes will be stamped out. Wiped off the map."

The events of 1933 had a direct effect on cabaret: very often, performers of Jewish descent or leftist sympathies left or kept a very low profile; cabarets experienced political pressure as Goebbels cracked down on political commentary; and the looming war meant that both audience members and performers were siphoned off by the draft. Other cabarets continued but the material was seriously curtailed. Paul Nikolaus, the conferencier of Kadeko, had committed suicide, saying "For once, no joke" (ibid.: 231). Although pre-scripted material could be censored, the spontaneous wit of the conferencier often proved less easy to control with their tradition of spontaneous witticisms and audience interaction. The conferencier role was excised by Goebbels altogether in 1941 and little would be left after that apart from partially naked dancing girls; there was no satire and jazz was condemned as decadent so bands such as the splendidly named Weintraub's Syncopators ${ }^{6}$ were legislated off the stage.

\section{5 "Unhealthy To-Do": Camp Cabaret}

In a remarkable postscript to the cabaret years, many participants continued to perform in the concentration camps to which they had been sent. Certain camp commandants sanctioned the troupes, membership of which could ensure some period of survival and they became much coveted, avoiding transportation to the extermination sites. Not all cabaret performers managed to get such coveted positions. Paul Morgan, conferencier of Kadeko, ended up in Dachau and finally Buchenwald where he perished in 1939.

\section{Brotherly Love: A Case Study of Contemporary British and German Comedic Exchange.}

\subsection{Dinner for One}

English manners enjoy a high reputation in Germany. One need only remark the German phrase, 'die feine Englische Art', roughly 'the fine English way', a phrase in common usage denoting a matter being effected in a particular refined fashion - a usage that is often preceded by the German speaker apologizing for their own actions not measuring up to said style. It is a style for which, as

\footnotetext{
${ }^{5}$ When asked if in 1939 Germany there was still any humour, Goebbels replied that "there is no country in Europe where there is as much joy than in Germany." (ibid.: 248)

${ }^{6}$ Literally the 'bunch of grape syncopators'. 'Syncopator' is an outdated term for a jazz musician - typically loaned into German from American English.
} 
a recent edition of the Stuttgarter Zeitung ${ }^{7}$ had it, 'Britons are respected the world over'. To an English native familiar with the chav-strewn insular car park Britain has become, the persistence of such a saying might seem at best incongruously quaint and, at worst, laughable.

Perhaps the whole saying is consistent with a larger pattern of loan words from English within the German language. To ignore the massive, and at times frequently inaccurate, pouring of English vocabulary into German occurring contemporarily, long standing English loan words within German include 'das Smoking' (loaned from a 'smoking jacket', meaning a 'dinner jacket'), 'ein Dandy' ${ }^{8}$ (entered into $19^{\text {th }}$ century German through the British dandy cult) 'ein Gentleman' (in common German usage alongside earlier the French gentilhomme), not to mention the odd 'Englischer Garten' or two (extant at Munich from 1789, for one). The importing of these words into historical German indicates an interest in and at times an appropriation of the accoutrements of the British class system. One might think of one famous $18^{\text {th }}$ century German in Britain, and his comment that his reception by George III on the $22^{\text {nd }}$ of November 1770 was "the happiest day of my life"; 9 the honoured guest and inventor of A4 paper, Professor Georg Lichtenberg. Today, this admiration is nowhere more apparent than in that slice of British class observation most central to German festivity, with its attendant catchphrase 'Same procedure as every year' - Dinner for One.

Dinner for One, ${ }^{10}$ also known by its German title 'Der 90. Geburtstag' ('The $90^{\text {th }}$ birthday'), is a just over 18-minute sketch filmed by the Norddeutscher Rundfunk (NDR) ${ }^{11}$ in 1963 and famous in Germany as screened, since the year of its existence, just under 300 times, chiefly as part of the German Silvester (New Year) celebrations. It is shown, in its original English, throughout the German speaking world and northern Europe during the festive season, although in Scandinavia it serves as a prelude to Christmas rather than New Year celebrations. ${ }^{12}$ The sketch itself dates back to the 1920's and the pen of the British revue author Lauri Wylie. Its chief actor, Freddie Frinton, a British character comedian, purchased the rights from Wylie and refined the sketch in British revues over the course of the 50's, until, in Blackpool in 1962, the sketch was taken up and shown in Frankenfeld's variety show 'Guten Abend,

\footnotetext{
7 From the article 'Sorry, please, thank you: Die Feine Englische Art' in the Stuttgarter Zeitung (25.06.07): "Das ist sie, die feine englische Art, die Selbstbeherrschung, für die man den Briten in der ganzen Welt Respekt zollt'.

8 A home grown German alternative to 'Dandy' exists, 'ein Geck'; however this word has a negative connation 'Dandy' does not possess, being a reference to the affected and as such incomprehensible manner of speech of a fop. Another possible variant as an Ur-Deutsch term for Dandy is a Stutzer.

9 See Baasner 2005: 94.

${ }^{10}$ Information courtesy of 'Ein Stück Fernsehgeschichte' at www.ndr. de; 'Dinner for One zu Silvester' at www. wdr. de.

${ }^{11}$ A Swiss version of only 11 minutes, including significant minor changes to the sketch, was filmed in March 1954.

12 The sketch was also briefly banned in Sweden for promoting alcohol abuse, but reinstated due to public demand.
} 
Peter Frankenfeld' and the rest, if still largely inexplicable, is history.

Despite occasioning various references and parodies, from puppets to satirical rewrites, ${ }^{13}$ the sketch remains unknown in its country of origin. As such a précis of its contents seems necessary. It is worth pointing out that the sketch has no specific relation to New Year; in fact, Dinner for One depicts the $90^{\text {th }}$ birthday party of 'Miss Sophie' (May Warden), an elderly lady of obvious means who is received at table by her butler James (Freddie Frinton) for a meal laid for four guests, Sir Toby, Admiral von Schneider, Mr. Pommeroy und Mr. Winterbottom. The hook of the sketch is that Miss Sophie is, as Heinz Piper ${ }^{14}$ puts it in the introduction in his fine German art, "nicht mehr die Jüngste", and as such has outlived all her dinner guests. As such James is forced to simulate the toasting that marks the start each course and, due to a mixture of sherry, white wine, champagne and port served over the four courses, becomes gradually very drunk. And that, give or take a bit of comedy business with a tiger skin rug, is that - the sketch proceeds with metronomic regularity, with each course of the meal starting with the following exchange:

James: The same procedure as last year, Miss Sophie?

\section{Miss Sophi.}

e: The same procedure as every year, James!

This exchange has become firmly established as a German national catchphrase and a sure ice breaker in any awkward German/Anglo cultural exchange ${ }^{15}$. It also serves to set up the sketch's pay-off, where, escorting a retiring Miss. Sophie to bed, after one more repeat of the above, James blusters:

James: Well, I'll do my very best!

Leaving the viewer to imagine what happens after the close of the sketch, without much difficulty.

As a critical analysis, the first thing that strikes a viewer of the sketch with any passing acquaintance with the history of British comedy is how old-fashioned it is. We are dealing here with a kind of end-of-the-pier comedy almost totally absent from the contemporary British comedy scene, unless by ironic inference, such as the Fast Show's Arthur Atkinson ${ }^{16}$ character. This sense is accentuated

\footnotetext{
13 Two examples: in 2003, a puppet version of the sketch previewed on the children's TV channel KIKA, starring 'Bernd das Brot' ('Bernd the bread') and 'Chili das Schaf' ('Chilli the sheep'); whereas, in 2000, the 'church cabaret' Klüngelbeutel (literally 'crony-bag') produced a version with the guests portrayed by leading religious figures (John II., Billy Graham etc.) Information at http://www.kluengelbeutel.de/.

14 Piper himself was a actor and television host, star of Der Mann, der sich verkaufte ('The Man who Sold Himself') and host of the first ever Eurovision song contest (won by Switzerland in 1956).

15 From the BBC correspondent William Horsley: 'I found myself in a bank in Berlin, on a second visit to open a bank account. The lady behind the counter was looking very strict, and handed over several forms in German for me to fill in. I looked over one of them, and asked innocently: "The same procedure as last year?" At once the stern bank lady unfroze. She glanced at me and said: "The same procedure as EVERY year, Herr Horsley!" And we both laughed'. Online at http://news.bbc.co.uk/2/hi/programmes/from_our_own_correspondent/3376853.stm.

${ }^{16}$ Atkinson was a parody of various music hall comedians, played by Paul Whitehouse in The Fast Show, 1994-2000.
} 
by its handsome black and white montage and charming narrated introduction, in which, after a preview of elegant classical music the aforementioned narrator fills us in more than comprehensively on the sketch's background, indicating the places of the attendant, imaginary guests. To an English comedy aficionado, watching all this might seem more alien than viewing a slice of contemporary German comedy with English subtitles, such as the current Stromberg, ${ }^{17}$ Ralf Husman's German 'interpretation' of The Office. The real question, then, is why this particular sketch has become so popular in Germany.

Our own answer is that the sketch's simple visual structure - the camera taking in the entirety of the table with only marginal rotations - and repetitive script afford it accessibility to Germans of differing ranges independent of their knowledge of English. Through Dinner for One, many Germans can gain access at New Year to a prestige brand, 'Britischer Humor', in much the same way as for the occasion one might drink French champagne or eat Scottish salmon. The sketch's repetition over a long period, and its touching on those most festive of themes, ritual and alcohol, together with a resultant happy adaptability to the drinking game, have embossed or indeed largely created its hilarity. And if there is residual incomprehension of the script's English that might play a role too; it is known that older Germans with very limited capabilities in English find the sketch uproariously funny, which begs the question of what exactly they are laughing at, apart from the ritual of the sketch itself - at which idea the notion of Kitsch peeks into view. It will be interesting to see if the current generation of younger Germans, often possessing advanced English language skills, turn away from Dinner for One in preference of a more sophisticated, perhaps even home-grown, slice of New Year comedy.

As a final comment, one might point out that Dinner for One is actually a rather cheery little number; it posits to the continuation of sexuality and sensual pleasure into an advanced age, and as such offers a positive sentiment at the start of another year. It is difficult to find such simple positives in much treatment of Germans in English comedy. German themes have consistently exercised English comedians, and usually exactly those themes absent from the gentle slapstick of Dinner for One; from Spike Milligan who "regularly sported Hitlerian regalia to get a laugh" 18 to Basil Fawlty's famous German meltdown. If we want to find an example of Anglo-Deutsch cultural exchange as unique as the aforementioned sketch we must turn to Basil Fawlty's earlier comedic venture, Monty Python.

\footnotetext{
17 Stromberg (2004-present) features the German theatre actor Christopher Maria Herbst as a German version of David Brent. The format copies the British The Office almost exactly, so much so that a compensatory sum was paid to Gervais and Merchant, the office's creator. As Gervais himself comments: "It's not like the Germans to just march in and take something that isn't theirs" (News of the World interview, courtesy of www.rickygervais.com).

18 See article in The Guardian of Thursday, July 4, 2002 by Stuart Jeffries: 'A Goosestep too Far'.
} 


\subsection{Monty Python}

In 1971-2, at the behest of the Westdeutscher Rundfunk (WDR), the increasingly famous Monty Python team recorded two episodes of 'Monty Python's Fliegender Zirkus' (Biolek 1998), a direct translation of Monty Python's Flying Circus. The second of these was a fairly standard, albeit handsomely mounted, episode of 'Monty Python', drawing on German themes and including among others the famous Philosopher's Football Match Sketch. The first episode though was performed entirely in German. It was premiered on ARD on 3/1/72 to an audience presumably only just getting over Dinner for One. As Michael Palin himself comments on the show's genesis:

[The WDR producer] felt that if we went out to Germany and made the sketches over there he would guarantee us a couple of really good shows and access to the burgeoning Germany market. (At the time, to be perfectly honest and a little racist we had not thought Germany was an obvious place for comedy, but we were wrong). ${ }^{19}$

Palin is therefore admitting, albeit with, yes, that fine English manner, that the team started from a traditional position of scepticism in relation to German comedy. The episode itself is a mixture of material old and new; a fast paced mosaic of familiar Python themes of cross-dressing, starlets, high culture and coarse jokes. The classic Python trope of calling a premature end to a sketch on grounds of silliness or general aggravation is revived ('Verschwinden Sie!' ${ }^{20}$ ), segueing into a version of the famous 'Lumberjack Song' sung in German supported with a supporting choir of the Austrian border police. To give you a sample of this, Palin's Lumberjack sings:

Holzfäller: Ich bin ein Holzfäller und fühl mich stark

Ich schlaf des Nachts und hack am Tag

Ich fälle Bäume, ich ess mein Brot

Ich geh auf das WC

Am Mittwoch geh ich Shopping

Kau Kekse zum Kaffee.

Which can be translated as:

Lumberjack: I'm a lumberjack and I feel strong

I sleep in the night and chop in the day

I fell trees, I eat my food,

I go to the WC,

On Wednesday I go shopping,

\footnotetext{
19 Interview courtesy of www-guerilla-films.com. This German market did indeed and has long existed; witness the Beatles recording versions 'Sie liebt dich' ('She Loves You') and 'Komm gib mir deine Hand' ('I wanna hold your hand') in 1964 or Laurel and Hardy's recently discovered Spuk um Mitternacht (from 1931).

20 Cleese's, during the game show parody 'Gut gesagt ist halb gewonnen': Showmaster: Verschwinden Sie! Schulz: Wie bitte? Showmaster: Ich sagte, verschwinden Sie, Sie uninteressante Person, Sie!
} 
Chew cookies with coffee. ${ }^{21}$

This is almost identical to the English text of the song with some minor, often contentious alterations. For example, as has been pointed out, the usage of 'Shopping' in the German text is incorrect; better would be 'shoppen', the actual loan verb for 'to shop'. And this is indicative of much of the response to this German Python episode - a puzzlement as to why the Pythons would want to perform in German, accompanied by appropriate criticisms of their use of the language. Much of the discussion has centred around the Verständlichkeit, (comprehensibility) of the show, as the Pythons themselves, with the honourable exception of Cleese, speak their (phonetically learned) lines with English accents. ${ }^{22}$ Sometimes this is used for arguable comic effect, as in Michael Palin's oft-given Bruce espousing upon 'das Rektum eines Känguruh' with a broad Australian accent, or Chapman playing a clueless American tourist stammering out guidebook phrases. Nonetheless, as Terry Gilliam says in the recent Pythons' autobiography (McCabe 2003), given the German tradition of dubbing all external broadcasts into German, a leading response to the team's performances in the language was 'Why did you bother?'

This ignores what even a casual observer of the show can see in it; a clear streak of Germanophilia, and a sense of the Python team living out their fantasies of German high culture with the WDR to foot the bill. The sketches riff on Albrecht Dürer, the greats of German philosophy and football; and all this against a background of glorious Bavarian sun. To this viewer at least, it looks like the Pythons are having a whale of a time; somewhat like how Dinner for One depicts an England of butlers and booze in accordance with German popular notions of 'The Island', the Python team are interacting with their Germany, of 'Dichter und Denker' - yet somewhere over the North Sea it ends up combined with low humour, such as the memorable flushing toilet sedan chair that ends the piece. The episode is to me an entirely admirable attempt by the Pythons to reach out and praise certain aspects of German culture. One suspects however, that the Pythons must have been somewhat underwhelmed by the response to their gesture of filming the episode in German; offering insufficient finances as the official reason, they returned to dubbed English for the second episode, filmed later and previewed on the $18^{\text {th }}$ December $1972 .^{23}$

The Python's had perhaps underestimated the horrifically sensitive contemporary relationship of many Germans to any externalization of their culture, no matter how apparently light-hearted. An anecdote told by Eric Idle about the episode's filming implies that such weightier issues were nonetheless on the

\footnotetext{
21 Source: 'Monty Python's Fliegender Zirkus' scripts, pp 22/23; online courtesy at http: //orangecow.org/pythonet/circus.html.

22 Varying accounts are given of the abilities of the Pythons in the German language, ranging from Cleese excelling by dint of being able to order a meal, to him being mistaken during filming for a German native.

23 The episode was subtitled, appropriately enough, 'Blödeln auf die feine englische Art' ('Fooling in fine English fashion'). Even more amusingly, the first episode was nicknamed 'Blödeln für Deutschland'. Perhaps the reader will now begin to become aware of the repetitiveness of the German conception of English comedy.
} 
Python team's minds. According to him, upon the initial proposal for the article, the Pythons were welcomed to Germany and driven, following 'huge Steins of beer', to the Dachau concentration camp, for reasons still apparently unclear to even Idle himself. Upon arrival, however, they were informed by a security guard that they were not allowed in, at which Graham Chapman apparently came back with "Tell them we're Jewish." ${ }^{24}$ An uncharitable analysis might attribute more wit to that remark than to the entirety of Dinner for One; another might see the existence of such national demons as a contributory factor in the German persistence with humour as unassuming as that of Freddie Frinton.

\section{Summary}

Seemingly, then, at this end of the article we have, rather than removed, doubled our collection of stereotypes; to the English stereotype of the humourless German even added the German stereotype of the humorvoll English person, locked in their eternal repetitive tripping over a tiger head rug. It is through this web of pre-conceptions that our book will have to weave. The article you have just read aims to provide a sample of the two main research strands of No Laughing Matter?; namely, a narrative account of the development of Germany stage comedy - represented by the historical overview in the first part of the article - alongside an investigation of the contemporary German comedy scene, represented by the subsequent analysis of Dinner for One.

That 'Comedyboomt' ${ }^{25}$ is oft-mentioned within reportage of the contemporary German entertainment industry; our research is an attempt to ascertain whether this boom really exists and, if so, locate it within a more specific and local continuity than the simple importation of Anglo-American perfomative models. Areas of research that may help to support this latter, contextualising intent are the description of indigenous German forms such as Schwank and Nachspiel and an investigation into the role of joking in the former East Germany. The book is by no means intended as a comprehensive survey of German comedy; rather, it aims to provide a broad and colourful sketch of what seems, even after the most perfunctory examination, a lively and distinctive comic tradition.

\section{Bibliography}

Baasner, Rainer (2005): Georg Christoph Lichtenberg: Aphorismen. Anaconda Verlag GmbH, Köln

Beare, Mary (1983): Hans Sachs: Selections. Durham: University Press

Biolek, Alfred (1998): Monty Python's Fliegender Zirkus: Sämtliche deutschen Shows. Zürich: Haffmans Verlag

\footnotetext{
${ }^{24}$ Anecdote told by Eric Idle during the 1998 reunion show 'Monty Python Live at Aspen'.

25 Source: Kai Niemeier online at http://www.webverzeichnis-webkatalog. de/DeutschesComedy-Portal-14587.html.
} 
Gillespie, Gerald (1992): German Theater Before 1750. New York: Continuum.

Grange, William (1996): Comedy In The Weimar Republic. Greenwood:

Westport

Jelavich, Peter (1993): Berlin Cabaret, Cambridge, Mass.: Harvard University Press

John, David G. (1991): The German Nachspiel In The $18^{\text {th }}$ Century. Toronto: University Press

McCabe, Bob (2003): The Pythons. London: Orion.

Schade, Richard E. (1988): Studies in German Comedy. Camden House:

Columbia

Scott-Prelorentzos, Alison (1982): The Servant In German Enlightenment

Comedy. Alberta: University Press

Terence, Publius Terentius Afer (1965): The Comedies. London: Penguin

The Guardian, 4/7/02. Article accessed online at

http://arts.guardian.co.uk/features/story/0, ,766092,00.html on 25.06.07

Stuttgarter Zeitung, 25.06.07. Article accessed online at www. stuttgarterzeitung. de on 26.06.07

The Fast Show, Series 1, UK, BBC, 1994.

The Fast Show, Series 2, UK, BBC, 1995.

'The Germans', Fawlty Towers, UK, BBC tx. 24/10/75.

Monty Python's Flying Circus - Live at Aspen, US, Python (Monty) Pictures, tx 21/03/98.

Monty Python's Fliegender Zirkus, Germany, Bavaria Atelier, Python (Monty) Pictures and Westdeutscher Rundfunk, tx. 08/09/71.

Der 90. Geburtstag oder Dinner for One, Germany, Norddeutschee Rundfunk

(NDR) and Schweizer Fernsehen (DRS), tx. 31. December, $1963 .^{26}$

http://www1.ndr.de/unterhaltung/dinner_for_one/dinner8.html Accessed 01/02/07

http://www.wdr.de/themen/panorama/extra/silvester2004/programmtipps/dinner_for_one.jhtml' Accessed 28/06/07

http://www.kluengelbeutel.de/ Accessed 01/06/07

http://news.bbc.co.uk/2/hi/programmes/from_our_own_correspondent/3376853.stm Accessed 01/07/07

http://www . guerilla-films.com Accessed 29/07/07

http://orangecow.org/pythonet/circus.html Accessed 30/06/07

www.rickygervais.com Accessed 30/06/07

\footnotetext{
26 This DVD contains the 11 minute 'Swiss' version of the sketch recorded in March 1963 and seems to have been released to cash in on the version recorded in Hamburg the same year. This version is viewable on YouTube or, of course, at German Silvester.
} 
http://www.schnitt.de/themen/artikel/gelfert_brits_und_krauts.shtml Taken from Schnitt: Das Filmmagazin \#47:03 2007 (A special themed edition on Monty Python's German reception and on respective German and British senses of humour). Accessed 04/10/07

http://www - webverzeichnis-webkatalog.de/Deutsches-Comedy-Portal-

14587.html Accessed 21/10/07

Books

Journals

Television

Websites 